\title{
TAXATION REGULATION OF THE BRICS' INNOVATIVE COMPANIES
}

\author{
ELENA MAKEEVA, \\ National Research University Higher School of Economics (Moscow, Russia) \\ IRINA MIKHALEVA, \\ National Research University Higher School of Economics (Moscow, Russia)
}

DOI: $10.21684 / 2412-2343-2018-6-1-41-62$

The question as to whether tax rate influences capital structure remains unresolved, though the amount of research conducted on the issue grows every year. This question is particularly important for innovative companies for two reasons. First, $R \& D$ spending and the level of innovativeness among firms are crucial indicators of a country's overall economic performance. The second reason is that tax incentive programs today are applied by governments with increasing frequency. There is a strong lack of tax rate influence on the capital structure of innovative companies and tax incentive programs impact on the debtto-equity ratio particularly. This research is intended to help fill this gap. The question as to the influence of tax rate as well as influence of $R \& D$ taxation programs on capital structure will be studied via the econometrics approach - that is, through panel regressions. The time frame to be considered is from 2012 until 2015. Four hypotheses connected with taxation influence on capital structure in BRIC countries were investigated. These hypotheses differ according to which indicator of the structure of capital is taken as the basis of the analysis. This investigation may be useful for governments or other analysts to estimate ETR influence on capital structure choice and assist in making a decision between increasing the tax rate (and thereby collect more taxes) versus stimulating companies to take on less debt and less risks. The results highlighted in this paper show an absence of significant impact vis-à-vis the tax rate on the capital structure and also indicate an absence of a significant impact of tax incentive programs on capital structure.

Keywords: R\&D; innovative companies; $R \& D$ taxation programs; effective tax rate; taxation policy. 
Recommended citation: Elena Makeeva \& Irina Mikhaleva, Taxation Regulation of the BRICS' Innovative Companies, 6(1) BRICS Law Journal 41-62 (2019).

\section{Table of Contents}

\section{Introduction}

\section{Literature Review}

1.1. The Influence of Tax Incentive Programs on Innovation

1.1.1. Causality Between Tax Incentive Programs and Performance

1.1.2. On R\&D Tax Incentive Programs

\section{Methods}

\subsection{Introduction to the Research Method}

\section{Data}

\subsection{Data Sources for BRIC Countries}

3.2. Data Sources for Data Set on Tax Stimulating Programs

\section{Hypotheses and Model Specification}

\subsection{On the BRIC Countries Data Set}

4.2. On the BRIC Countries Model Specification

\section{Results}

\subsection{Results Anticipated}

\subsection{Results Obtained from the BRIC Countries Data Sample} Conclusion

\section{Introduction}

Information and intangible assets such as knowledge seem to play a central role in economic success in the $21^{\text {st }}$ century, both on micro and macro levels of investigation. Innovative knowledge is what matters today, and what distinguishes winners from losers. From a macroeconomic perspective, it can mean that a country which successfully implements innovative knowledge in different economic and social spheres has a good chance to outpace competitors in terms of economic progress in a relatively short period of time. On the microeconomic level, it means that a firm which has high R\&D spending is incentivized to lead innovative progress and develop existing production either qualitatively or quantitatively, and in a few years may well have a competitive advantage over its rivals.

Recent studies on capital structure contradict each other when it comes to naming the factors influencing firms' choice of financing operations. One of the main issues here is whether corporate tax rate affects capital structure choice and, if and where it does so, to what specific extent it has such an effect. This issue is particularly important in studies of innovative companies for the following reasons: since R\&D 
spending and the level of innovativeness among its firms are crucial for a country's overall economic performance, fiscal policy often provides innovative companies with beneficial tax programs, usually referred to as "tax stimulating innovation policies."There are several types of such programs, among which the most popular are "R\&D tax credit," "R\&D super deduction," and "innovation" or "patent box regimes." These policies are common not only in developed countries but also in transitional economies or developing countries where they have been recently adopted.

The majority of capital structure research is focused on understanding forces that influence corporate financing choice in developed countries, mainly in the United States. However, over the last few years, scientific interest in similar trends pertaining towards developing countries has increased. Though there are more papers referring to such countries as China and Brazil today, there is still lack of research in developing countries looking into the applicable variables influencing corporate financing behavior and corporate tax rates specifically. This paper focuses on this area specifically, referring to the data on innovative companies in BRIC countries' to analyze the effect of tax rates on corporate structure choice.

Problem Statement. The purpose of this paper is to measure the impact of effective tax rate influence and tax stimulating programs on corporate structure choice for a sample group of firms based in Brazil, Russia, India and China. It is important to note that, originally, the authors planned to analyze R\&D tax credit, $R \& D$ super deductions, and innovation and patent box regime influence on corporate structure choice separately. If that was to be done, this study would become the first one we know of thus far which considers the issue of tax stimulating programs' influence on capital structure. However, due to a lack of available data we were unable to do such an analysis for BRIC countries. Since we are still specifically interested in such impact, we analyzed the impact of tax stimulating programs on the capital structures of innovative companies for more developed countries instead, for which more data is available. We hope that one day our study will serve as a template for a similar analysis of BRIC countries when more data on these countries becomes widely available for economics research.

\section{Literature Review}

\subsection{The Influence of Tax Incentive Programs on Innovation}

\subsubsection{Causality Between Tax Incentive Programs and Performance}

For the purposes of this paper, the existing literature on tax incentive programs influence on company's performance (on R\&D quantity and quality to be precise) must be analyzed. There is no doubt that the causality between performance and capital structure exists - the issue today is whether high-performance innovative companies use debt financing more often than less successful parties. It was already mentioned that debt financing is easier for companies with high-quality R\&D and that patents can even be used as a guarantee on bank debt. 
Bloom, Griffith, and Van Reenen's (1999)' early paper separately analyzes the influence of tax credits on R\&D. Using panel data on tax changes from eight OECD countries, research concludes that tax credits increase R\&D intensity, or quantity, in these countries. However, most of the countries analyzed in that paper are developed countries such as the United States, the United Kingdom, and Canada. The research also uses data from Spain, and we would apply these results, though our paper mainly focuses on BRIC countries, none of which are analyzed in Bloom, Griffith, and Van Reenen (1999).

The Hall and Van Reenen (2000) $)^{2}$ survey summarizes evidence of fiscal incentives for R\&D and concludes that each dollar in tax credit for R\&D stimulates one dollar of R\&D additional spending, expanding R\&D. However, this study emphasizes that the information gained on the topic and the amount of literature was yet insufficient.

The Karkinsky and Riedel (2012) ${ }^{3}$ article analyzes corporate patents in multinational firms as a source of profit-shifting opportunities and a correlation between corporate tax rate and the number of patents holds in the country. The paper shows that there is a strong negative effect between tax rate for corporations and the number of patent applications filed. Though our study does not focus on MNE, the result of the Karkinsky and Riedel study is important for our analysis since it shows that the lower the corporate tax rate, the higher the performance showed by the innovative firm in terms of quality - that is, in terms of patents registered.

The Ernst, Richter, and Riedel (2013) ${ }^{4}$ study focuses not only on the issue of tax incentive programs' influence on R\&D spending, but also whether these programs expand R\&D quality, directly heightening companies' performance. The conclusions of this paper are highly useful. It discusses a recently introduced tax incentive program - reduced income tax rates on R\&D output - which is the only one so far influencing R\&D quality instead of quantity. The rest of the programs, (i.e. special tax allowances and tax credits) do influence the quantity of R\&D spending, but not the quality of results. The implication of these results is the following: while special tax allowances and tax credits benefit from R\&D input, reduced income tax rates on $R \& D$ benefit through output.

Nick Bloom et al., Do R\&D Tax Credits Work? Evidence from an International Panel of Countries 1979-1994, Institute for Fiscal Studies, Working Paper No. W99/8 (1999).

2 Bronwyn Hall \& John van Reenen, How Effective Are Fiscal Incentives for R\&D? A Review of the Evidence, 29(4-5) Research Policy 449 (2000).

3 Tom Karkinsky \& Nadine Riedel, Corporate Taxation and the Choice of Patent Location Within Multinational Firms, 88(1) Journal of International Economics 176 (2012).

4 Christof Ernst et al., Corporate Taxation and the Quality of Research and Development, 21 (4) International Tax and Public Finance 694 (2014). 


\subsubsection{On R\&D Tax Incentive Programs}

Different $R \& D$ tax incentive programs aim to make economies more competitive. First, we will examine existing types of R\&D tax incentives. There are three main categories of incentive: "R\&D tax credits," "R\&D tax super deductions" and "patent box regimes." $R \& D$ tax credit is an amount subtracted directly from the tax liability. Programs may vary by whether the tax credit is refundable, taxable, or based on the volume of R\&D. Regardless of the specific type, tax credit works through decreasing taxable income. The second type of R\&D incentive - R\&D tax super deductions also decreases the taxable income, but instead of decreasing it on the different percentage which varies depending on other factors, super deduction does so based on the fixed value of the R\&D assets or capital. The program looks almost the same as the tax credit, but companies using it can reduce their taxable income even more. By way of example, super deduction base reaches $300 \%$ in Latvia and Lithuania. Finally, patent box regimes use another principle - they decreases corporate tax rate for patents income, making holding patents even more beneficial.

Table 1 is examines how these programs are used in various countries according to the nature of the benefit available. One of the most popular incentives is certainly tax credit, available in most countries observed:

Table 1: Tax Credit Practice by Country

\begin{tabular}{|c|c|}
\hline Country & Details on tax credit \\
\hline \multicolumn{2}{|l|}{ BRICS } \\
\hline Russia & $\begin{array}{l}\text { Tax credit may be provided for one to five years and shall not exceed } \\
50 \% \text { of a taxpayer's total payment for the period. In addition, the } \\
\text { investment tax credit shall not exceed 100\% of the acquisition value } \\
\text { of fixed assets that are to be used in R\&D activity or can be negotiated } \\
\text { with the authorities }\end{array}$ \\
\hline \multicolumn{2}{|c|}{ Other countries } \\
\hline Australia & $\begin{array}{l}\text { A refundable } 45 \% \text { tax credit for SMEs and nonrefundable tax credit } \\
\text { of } 40 \% \text { of large firms }\end{array}$ \\
\hline Austria & $10 \%$ volume-based refundable credit \\
\hline Canada & $\begin{array}{l}15 \% \text { tax credit for all qualifying R\&D costs and refundable investment } \\
\text { tax credits at a rate of } 35 \% \text { for small Canadian-controlled private } \\
\text { corporations }\end{array}$ \\
\hline France & $\begin{array}{l}30 \% \text { tax credit for the first EUR } 100 \mathrm{M} \text { of qualified } \mathrm{R} \& \mathrm{D} \text { expenditure } \\
\text { incurred during the tax year. For qualified research expenditure above } \\
\text { this EUR } 100 \mathrm{M} \text { threshold, the rate is reduced to } 5 \%\end{array}$ \\
\hline Ireland & $25 \%$ volume-based tax credit \\
\hline Italy & $\begin{array}{l}\text { Incremental R\&D tax credit equal to either } 25 \% \text { or } 50 \% \text { depending on } \\
\text { the size of the company and } 25 \% \text { credit for digital economy }\end{array}$ \\
\hline
\end{tabular}




\begin{tabular}{|l|l|}
\hline Japan & $\begin{array}{l}\text { Differentiated volume-based credits: for SMEs the rate is 12\% of total } \\
\text { R\&D expenditure and for all other companies the rate is } 8 \% \text { to } 10 \% \\
\text { of total R\&D expenditure }\end{array}$ \\
\hline Portugal & $\begin{array}{l}\text { Atax credit of } 32.5 \% \text { of the R\&D expenditure and } 50 \% \text { of the incre- } \\
\text { mental expenditure of the period is available }\end{array}$ \\
\hline South Korea & $\begin{array}{l}\text { Volume-based and incremental tax credits for SMEs and large } \\
\text { companies }\end{array}$ \\
\hline Spain & $\begin{array}{l}\text { Volume-based tax credits for } 25 \% \text { of qualified expenditure and } \\
\text { Incremental credit equal to } 42 \% \text { of the amount of current year } \\
\text { expenditure }\end{array}$ \\
\hline UK & $\begin{array}{l}10 \% \text { refundable credit for large companies and 33.35\% refundable } \\
\text { credit for SMEs }\end{array}$ \\
\hline USA & \begin{tabular}{l} 
Incremental research tax credits \\
\hline
\end{tabular}
\end{tabular}

Source: Deloitte working papers.

Super deductions are widespread as well, performed in the following countries (represents in the Table 2) under diverse conditions.

Table 2: Super Deduction Practice by Country

\begin{tabular}{|c|c|}
\hline Country & Details on super deduction \\
\hline \multicolumn{2}{|l|}{ BRIC } \\
\hline Brazil & $160 \%-200 \%$ super deduction \\
\hline Russia & $150 \%$ super deduction \\
\hline India & $\begin{array}{l}200 \% \text { super deduction for in-house R\&D expenditure and } 125 \%- \\
200 \% \text { super deduction for payment to research institutions }\end{array}$ \\
\hline China & $150 \%$ super deduction \\
\hline \multicolumn{2}{|c|}{ Other countries } \\
\hline Belgium & $\begin{array}{l}\text { A one-time deduction of } 13.5 \% \text { of all R\&D investments or a current } \\
\text { deduction of } 20.5 \% \text { of depreciation related to R\&D assets }\end{array}$ \\
\hline Croatia & $\begin{array}{l}\text { Depending on the project category: fundamental research project - } \\
250 \% \text {, applied research project }-225 \% \text {, developmental research } \\
\text { project }-200 \% \text {, technical feasibility studies }-175 \%\end{array}$ \\
\hline $\begin{array}{l}\text { Czech } \\
\text { Republic }\end{array}$ & $200 \%$ super deduction \\
\hline Hungary & $200 \%$ super deduction \\
\hline Latvia & $300 \%$ super deduction \\
\hline Lithuania & $300 \%$ super deduction \\
\hline Malaysia & $200 \%$ super deduction \\
\hline Netherlands & $160 \%$ super deduction \\
\hline
\end{tabular}




\begin{tabular}{|l|l|}
\hline Poland & $100 \%$ super deduction \\
\hline Romania & $150 \%$ super deduction \\
\hline Singapore & $\begin{array}{l}\text { Additional } 50 \% \text { deduction for certain R\&D expenses incurred in } \\
\text { Singapore and additional } 250 \% \text { or } 300 \% \text { deduction on the first SGD } \\
400 \mathrm{~K}\end{array}$ \\
\hline South Africa & $150 \%$ volume-based super deduction \\
\hline Turkey & Incremental 100\% deduction \\
\hline UK & $\begin{array}{l}130 \% \text { volume-based super deduction for large companies, } 230 \% \\
\text { volume-based super deduction for SMEs }\end{array}$ \\
\hline
\end{tabular}

Source: Deloitte working papers.

Patent box regimes are a less popular measure though it is also used in several countries. Data are shown in the Table 3.

Table 3: Patent Box Regime Practice by Countries

\begin{tabular}{|l|l|}
\hline Country & Details on patent box regime \\
\hline BRIC & $\begin{array}{l}\text { Income by way of royalty in respect of a patent developed and } \\
\text { registered in India earned by an eligible taxpayer shall be subject to } \\
\text { tax at the rate of 10\% (plus surcharge and cess) on a gross basis }\end{array}$ \\
\hline China & $\begin{array}{l}\text { China extends its patent box to allow income from certain types } \\
\text { of commercial "know-how". Exemption for revenue below RMB 5M } \\
(\$ 783 \mathrm{~K}) \text { and } 50 \% \text { above RMB 5M. Tax Rate - 12,5\% }\end{array}$ \\
\hline Other countries \\
\hline Belgium & Patent income deduction of $80 \%$ of qualifying patent income \\
\hline Hungary & $\begin{array}{l}\text { A patent box deduction from income tax 50\% of the gross amount } \\
\text { of the royalty received }\end{array}$ \\
\hline Italy & $50 \%$ tax exemption that will be phased-in over a 3-year period \\
\hline UK & $10 \%$ patent box deduction \\
\hline
\end{tabular}

Source: Deloitte working papers.

It is important to once again highlight that there are several other tax incentive programs that are not covered here - measures which are specific to certain countries. Some countries listed above use several programs: for instance, the United Kingdom uses all three types of programs mentioned above, while Turkey has only a $100 \%$ incremental super deduction. Today there are many studies held on the subject of whether tax incentive programs achieve their goal of enhancing R\&D spending. However, economic science is still undecided on the issue, so it is hard to be sure at this point whether using more or less tax incentive programs is beneficial or not. 


\section{Methods}

\subsection{Introduction to the Research Method}

This research consists of two separate but closely related parts. In the first part, effective tax rate (ETR) influence on the capital structure of innovative firms from BRIC countries will be analyzed. For this purpose, we use a panel data set [2012-2016 years] of companies from Brazil, Russia, India, and China. We had planned to include South Africa in our data set as well, but our research revealed a significant lack of data on this country and virtually no companies that would meet our definition of innovative companies.

In the second part, we observe not only effective tax rate impact on the capital structure, but tax influence is decomposed into three components by tax incentive programs - R\&D tax credit, R\&D super deduction, and patent box regime. For that purpose, another data set is used - though, as we have noted, despite tax incentive programs becoming more popular and widespread in developing countries (including BRIC countries), corporate culture in these countries still lacks transparency, which leads to a lack of reliable data from sources such as the financial statements of companies. Moreover, the relative novelty of tax incentive programs throughout the world leads to another data related issue - that is, the fact that it is hard to compose even a relatively balanced panel data set (which would contain tax variables decomposed according to taxation programs) even if one were analyzing developed rather than developing countries. That is why one-year data from 21 developed countries' innovative companies is used in this study to bring an approximate estimation of tax stimulating programs effect on capital structure choice.

\section{Data}

\subsection{Data Sources for BRIC Countries}

Our main data source for both parts of our research is Bloomberg Terminal, and the data was analyzed using data analysis program Stata 13. Bloomberg Terminal is a widelyused computer software system provided by financial data vendor Bloomberg. This system contains real-time updated verified data on a wide range of financial variables.

We based our research on BRIC countries on the 2012, 2013, 2014, 2015 fiscal years' data from Bloomberg, which contains financial data for innovative firms which are headquartered in and trade in BRIC countries. We have preferred to use panel data in this part of our research over cross-sectional data which we use in second part of our research due to some valuable panel data advantages:

- as we have already mentioned, there is significantly less verified data available on BRIC countries' companies in comparison to firms based in developed countries. Lack of recorded observations may lead to serious problems in regression construction in instances of insolvency. One way to deal with the issue is to use panel data which 
enlarge the number of observations and improve the effectiveness of evaluations, for example:

- using panel data makes it possible to analyze the influence of independent variables on the dependent ones over a certain time interval, which is particularly important for our research since an overview of company investments in R\&D over a certain time interval is more objective.

The data was primarily selected according to the following criteria:

- Where the countries of domicile are Brazil, Russia, India, China;

- Where R\&D spending for each year observed [2012-2016] has data;

- Where R\&D spending value for each year observed [2012-2016] is greater than zero;

-Where total assets for each year observed [2012-2016] has data or value is greater than zero.

Therefore, we include in the data set those firms that have total assets and R\&D spending data for 5 years and whose securities are currently traded. As a result of this selection, observations from 2,690 companies were primarily received, which, in total, composed 13,450 observations. Each company was given a unique id number, which, further on, was set as panel variable. Data duplicates were detected and erased using the duplicate function in Stata 13. Data outbursts were detected by a graphical analysis of data for each variable grouped by year, implemented in Microsoft Office 365 Excel. Uploading data from Bloomberg Terminal was transformed into panel structure with the help of an add-in Power Query.

The next step in the data analyses was performed in Stata 13 with a normal distribution of errors verification. Verification was made using the -qnorm- function, which displays an error distribution graph. For each of the variables, distribution graphs showed reverse normality with the exception of some omissions, which were erased. Further, the data were checked for multicollinearity by compiling an independent variables correlation matrix.

After performing this data selection process, we ended up with the sample of 1,508 companies, which corresponds to 7,540 observations. Company distribution by country is presented in the Table 4 below.

Table 4: Company Distribution by Country

\begin{tabular}{|c|c|c|c|}
\hline Country & $\begin{array}{c}\text { Number } \\
\text { of companies }\end{array}$ & $\begin{array}{c}\text { Number } \\
\text { of observations }\end{array}$ & $\begin{array}{c}\text { Percentage in the } \\
\text { total sample }\end{array}$ \\
\hline Russia & 6 & 30 & $0.398 \%$ \\
\hline Brazil & 23 & 115 & $1.525 \%$ \\
\hline China & 1054 & 5270 & $69.894 \%$ \\
\hline India & 90 & 450 & $5.968 \%$ \\
\hline
\end{tabular}

Source: Author's own calculations. 


\subsection{Data Sources for Data Set on Tax Stimulating Programs}

For initial data set from 21 developed countries on tax stimulating programs we used Bloomberg terminal as well with the same primary constraints. However, there is no data available in any financial aggregator as we know so far which would provide separate data on tax incentive programs.

Therefore, data collection for this sample was a two-stage process. For the first stage, data from Bloomberg Terminal on basic control variables was collected (the same set of control variables as in the earlier BRIC countries sample was utilized) as well as data on effective tax rates, while the second stage process consisted of a manual data search and sample collection. Instead of using panel data, in this case we used cross-sectional data from the same year [2016] from 21 developed European countries: Australia, Belgium, Denmark, Finland, France, Germany, Greece, Hungary, Iceland, Ireland, Italy, Luxemburg, Netherlands, Norway, Poland, Portugal, Slovenia, Spain, Sweden, Switzerland, and the UK. The final distribution of companies for these countries is shown in Figure 1.

Fig. 1: Company Distribution by Country
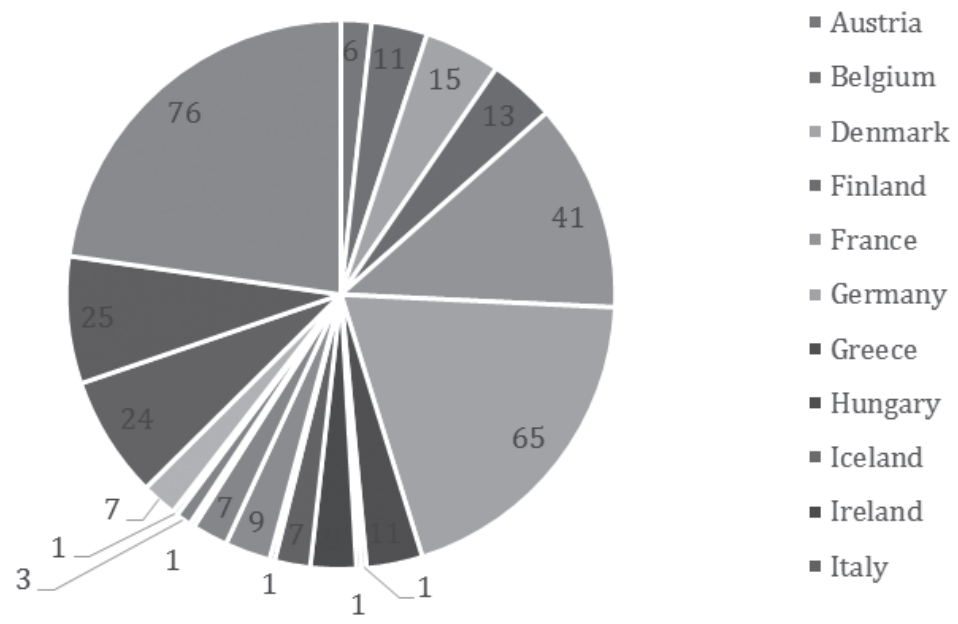

Source: Author's own calculations.

As previously described, the three different types of tax incentive programs $R \& D$ tax credit, $R \& D$ super deduction and patent box regime - impact on capital structure is analyzed here. Tax incentive programs are implemented in the model as three different dummy variables, which equal 1 if the company participated in program and 0 if no participation took place. For the data which could not be found these variables accommodate the missing value. The main source for these "dummy 
variables" data is the annual financial reports of the individual companies (notes section). In the official governmental accounts of the countries surveyed, as opposed to each company's individual reporting, the relevant information was presented in sufficient detail to enable it to be possible to find data for the sample according to the category of incentive programs. This may be one of the reasons why these dummy variables coefficients are insignificant.

In this sample mainly developed countries were included. Some countries such as Slovenia, Hungary and Poland are relatively less developed than others in the category, but they are still considered to be developed; the only country which is under debate is Greece, but since this country is a member state of the European Union, we may also consider it to be developed. Regardless, in this research model we did not distinguish between developed and developing countries for two reasons. First, the goal of this part of our research is to make a rough estimate of tax incentive programs' influence on capital structure without distinguishing results by economic development of the individual countries. Second, not enough data is available to make such a distinction.

The last peculiar characteristic of the data to take notice of here, is that during the process of collecting information vis-à-vis companies' participation in tax incentive programs it became apparent that there is a relatively low participation rate in these programs, which lowers again in relative terms as we move down the order of development for these countries (from more developed to less developed). This is a rough estimate and needs to be proven via a more thorough econometric analysis. In this case, analysis is based on simple observation. The share of companies' participation in various programs $-R \& D$ tax credit, $R \& D$ super deduction and Patent Box Regime according to our data can be observed on Figure 2 .

Fig. 2: Companies' Participation in Tax Incentive Programs

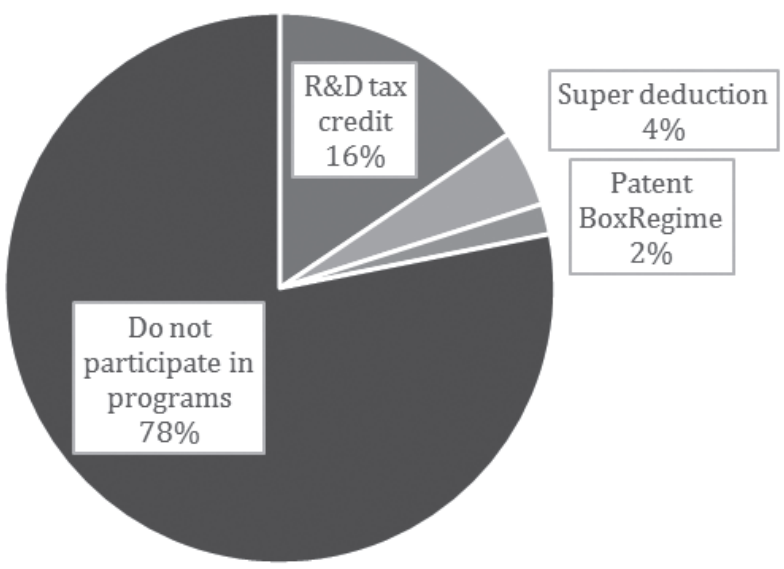

Source: Author's own calculations. 
Thus, this data set includes financial indicators from 21 countries and 334 companies. Among these companies 261 company do not participate in tax incentive programs, though such programs exist in these countries. Any notable lack of participation can occur due to various reasons (such as companies' ignorance towards such programs).

\section{Hypotheses and Model Specification}

\subsection{On the BRIC Countries Data Set}

The study on the BRIC countries data set tests four main hypotheses, which demonstrate the impact of taxation on the capital structure of innovative companies. These hypotheses differ according to which indicator of the structure of capital is taken as the basis of the analysis.

With regard to incentive programs, as we have already noted, separate analyses of their influence on capital structure is impossible for now due to the lack of required data. However, we would like to note that the use of a variety of incentive programs is increasingly prevalent in BRIC countries. Nowadays virtually all the types of stimulation programs which prevail in developed countries are used in BRIC countries as well.

Table 5: The Policy of Stimulating Innovation in Developed Countries

\begin{tabular}{|l|c|c|c|}
\hline \multicolumn{1}{|c|}{ Countries } & R\&D tax credit & $\begin{array}{c}\text { R\&D super } \\
\text { deduction }\end{array}$ & $\begin{array}{c}\text { Innovation } \\
\text { or patent box } \\
\text { regime }\end{array}$ \\
\hline Australia & + & & + \\
\hline Belgium & + & + & + \\
\hline Denmark & + & & + \\
\hline France & + & & + \\
\hline Ireland & + & & + \\
\hline Japan & + & & + \\
\hline Netherlands & + & + & + \\
\hline South Korea & + & & + \\
\hline Switzerland & & & + \\
\hline United Kingdom & + & + & \\
\hline USA & + & & \\
\hline
\end{tabular}

Source: Author's own calculations. 
Table 6 shows the existing tax programs and indicates whether they are present in a particular developed country.

Table 6: The Policy of Stimulating Innovation in BRIC Countries

\begin{tabular}{|l|c|c|c|}
\hline \multicolumn{1}{|c|}{ Countries } & R\&D tax credit & $\begin{array}{c}\text { R\&D super } \\
\text { deduction }\end{array}$ & $\begin{array}{c}\text { Innovation or } \\
\text { patent box regime }\end{array}$ \\
\hline Brazil & & + & + \\
\hline China & & + & + \\
\hline India & & + & \\
\hline Russia & + & + & + \\
\hline
\end{tabular}

Source: Author's own calculations.

The table above (Table 6) shows the existing tax programs and indicates whether they are present in a specific developing country (in this case, the BRIC countries).

In our study, we derived the following hypotheses based on the existing literature and different indicators of a company's capital structure. We use four different indicators - that is, four different dependent variables: Total Debt/Total Equity, Net Debt/Total Equity, Short term Debt/Total Equity, and Long term Debt/Total Equity.

The hypotheses therefore are:

$\mathrm{H10}$ : The impact of effective tax rate [ETR] in BRIC countries on Total Debt/Total Equity is statistically significant.

$\mathrm{H11}$ : The impact of effective tax rate [ETR] in BRIC countries on Total Debt/Total Equity is statistically insignificant.

$\mathrm{H} 20$ : The impact of effective tax rate [ETR] in BRIC countries on Net Debt/Total Equity is statistically significant.

$\mathrm{H} 21$ : The impact of effective tax rate [ETR] in BRIC countries on Net Debt/Total Equity is statistically insignificant.

$\mathrm{H} 30$ : The impact of effective tax rate [ETR] in BRIC countries on Short term Debt / Total Equity is statistically significant.

$\mathrm{H} 31$ : The impact of effective tax rate [ETR] in BRIC countries on Short term Debt / Total Equity is statistically insignificant.

H40: The impact of effective tax rate [ETR] in BRIC countries on Long term Debt / Total Equity is statistically significant.

$\mathrm{H} 41$ : The impact of effective tax rate [ETR] in BRIC countries on Long term Debt / Total Equity is statistically insignificant.

To reveal the effect of taxation on capital structure choice, the effective tax rate (ETR) is utilized as an indicator. ETR is the ratio of income tax expense to pre-tax financial income and has been widely used in research (Klapper and Tzioumis, 2008). 
ETR is firm-specific, but since we apply an innovative large firms' data set, this fact should not lead to statistical bias.

This study applies the following panel-data specification:

$$
\text { Yit }=a i+\beta i X i t+\gamma i E T R i t+\varepsilon i t
$$

Where $Y$ represents the debt-to-equity ratio [depending on specification], $X$ is a vector of control variables, ETR stands for effective tax rate, a denotes firm-specific factors, $\beta$ and $\gamma$ represent coefficients of $X$ vector and ETR accordingly and $\varepsilon$ denotes the residuals.

With regard to control variables, we use a series of variables which theoretically influence firms' financing decisions and were utilized in previous studies. The set of variables is shown in the Table 7.

Table 7: Variables Summary

\begin{tabular}{|l|l|}
\hline \multirow{4}{*}{ Type } & Variables \\
\hline \multirow{5}{*}{ Dependent variable } & Total Debt-to-Total Equity ratio \\
\cline { 2 - 2 } & Net Debt-to-Total Equity ratio \\
\cline { 2 - 2 } & ST Debt-to-Total Equity ratio \\
\cline { 2 - 2 } & LT Debt-to-Total Equity ratio \\
\hline \multirow{5}{*}{ Control variables } & Revenue [logarithmic] \\
\cline { 2 - 2 } & Tangibility \\
\cline { 2 - 2 } & Return on assets [ROA] \\
\cline { 2 - 2 } & Current ratio [CR] \\
\cline { 2 - 2 } & R\&D-to-Net Sales ratio \\
\cline { 2 - 2 } & R\&D Expense [logarithmic] \\
\hline Main independent variable & ETR (effective tax rate) \\
\hline
\end{tabular}

Source: Author's own calculations.

Certain of the variables in the above model warrant some brief explication:

1. Revenue (used in models as rev). The main purpose of using this variable is as an indirect indicator of a company's size. This variable (or its analogue - Sales) is used in almost every existing study on capital structure and the factors influencing it. In the regression, in order to receive weighted data, we used a logarithmic version of this variable, generated by gen rev=In(Revenue) command in Stata 13.

2. Tangibility (used in models as tang). Is calculated in Excel as Property, Plant and Equipment/Total Assets.

3. $R \& D$ Expense (used in models as rd_exp). According to the data selection criteria, it is a non-zero variable. In the regression, in order to receive weighted data we used a logarithmic version of this variable, generated by gen rd_exp=In(RD_Exp) command in Stata 13. 
Table 8 shows a summary of statistics on all the independent variables. Normality of errors of variables is observed as well as lack of multicollinearity. The criterion for the absence of multicollinearity was the absence of a correlation exceeding 0.7 in the correlation matrix of independent variables [Table 9].

Table 8: Summary of Statistics

\begin{tabular}{|l|l|l|l|l|l|}
\hline Variable & Obs & Mean & Std.Dev & Min & Max \\
\hline etr & 6693 & 2.88349 & 1.66978 & -6.9148 & 27.5537 \\
\hline roa & 6798 & 1.69440 & 2.01185 & -5.6775 & 27.6207 \\
\hline tang & 6936 & -1.1150 & 1.08573 & -10.137 & 7.11305 \\
\hline cr & 7539 & .803043 & 2.05032 & -2.4602 & 27.4405 \\
\hline rd2ns & 7539 & .941389 & 2.28360 & -9.7046 & 27.6294 \\
\hline rev & 7539 & 21.2349 & 1.84163 & 12.0097 & 29.4411 \\
\hline rd_exp & 7540 & 17.4688 & 1.70337 & 7.60090 & 24.3427 \\
\hline
\end{tabular}

Source: Author's own calculations.

Table 9: Correlation Matrix of Independent Variables

\begin{tabular}{|l|l|l|l|l|l|l|l|}
\hline & Rd_exp & rev & Rd2ns & etr & tang & roa & $\mathrm{Cr}$ \\
\hline rd_exp & 1.0000 & & & & & & \\
\hline rev & 0.6122 & 1.0000 & & & & & \\
\hline rd2ns & 0.2263 & -0.2685 & 1.0000 & & & & \\
\hline etr & -0.0058 & 0.0739 & -0.0694 & 1.0000 & & & \\
\hline tang & -0.0111 & 0.1291 & -0.1202 & 0.0220 & 1.0000 & & \\
\hline roa & -0.0565 & -0.1164 & 0.0756 & -0.0339 & -0.0606 & 1.0000 & \\
\hline cr & -0.0580 & -0.1458 & 0.0707 & -0.0281 & -0.0818 & 0.0474 & 1.0000 \\
\hline
\end{tabular}

Source: Author's own calculations.

\subsection{On the BRIC Countries Model Specification}

There are several ways to approach panel data analyses. For example, a basic linear regression may be constructed without utilizing the panel data structure. Such an analysis does not allow one to consider the dynamics of variables, however, it still may use one of the main panel data advantages, that is, more observations, which reduces statistical bias. Before using panel data, we tried to use cross-sectional data instead and a basic linear model, but the results of such a regression turned out to be 
unreliable. This was mainly due to an insufficient number of observations, especially after the removal of duplicates and omissions [only 174 observations could be used in that sample]. Thus, first we used a basic linear regression built on panel data.

The next model used to obtain results was a fixed effects model. With this approach, regression "within" was estimated. "Within" regression is an original regression model [1], rewritten in terms of variable values deviations from timeaveraged values:

$$
\text { Yit }- \text { Yiav. }=a i+\beta i(\text { Xit }- \text { Xiav. })+\gamma i(\text { ETRit }- \text { ETRiav. })+\text { zit }- \text { ziav. }
$$

Where $Y$ represents the debt-to-equity ratio [depending on specification], Yav. represents a time-averaged dependent variable value, $X$ is a vector of control variables and Xav. is a vector of these variables time-averaged values, ETR stands for effective tax rate and ETR av. stands for effective tax rate time-average, a denotes firm-specific factors, $\beta$ and $\gamma$ represent coefficients of $X$ vector and ETR accordingly and $\varepsilon$ denotes the residuals.

This model allows one to eliminate unobserved observations from their regression; the coefficient values in the model are estimated using ordinary OLS. "Within" regression estimates regression with fixed effects (FE), meaning that $\beta w$ est. $=\beta F E$ est. Fixed effects model was estimated for the following independent variables etr, rd_exp, rd2ns, rev, tang, roa, cr using four regressions, each constructed on different dependent variables d2e, net_debt2e, st_debt2e, It_debt2e.

For the next step, the random effects model was estimated using four regressions constructed on the same dependent and independent variables. The random effects model is a compromise between cross-section regression (which imposes a strong restriction on coefficients' homogeneity) and fixed effects regression, which allows one to assign a unique constant for each sample object.

An advantage of the random effects model compared to the fixed effects model is that time invariant variables can be included. It should be used in the case when differences across entities [innovations companies] have some influence on dependent variables. In the case of the BRIC countries data set this might be the case, since though all the countries in the data set are developing countries, their institutional settings are diverse. To eliminate this effect, the spatial category $\mathrm{n}_{-}$ country is used, which contains a unique number from 1 to 4 assigned to each country, by applying the $n \_c o u n t r y$ function in Stata 13, the risk of an intercountry difference impacting on dependent variables is to some extent prevented. The regression model for random effects is written as follows:

$$
\text { Yit }=a i+\beta i X i t+\gamma i E T R i t+u i t+\varepsilon i t
$$

Where $Y$ represents a debt-to-equity ratio [depending on specification], $X$ is a vector of control variables, ETR stands for effective tax rate, a denotes firm-specific factors, $\beta$ and $\gamma$ represent coefficients of $X$ vector and ETR accordingly, $\varepsilon$ denotes within-entry error and $u$ denotes between-entry error. Random effects model was 
estimated for the same variable as fixed effects model. For this estimation the GLS method is applied.

To compare last two models in terms of efficiency, a Hausmann test was conducted. At any reasonable level of significance, the null hypothesis [Ho: the difference in coefficients is not systematic] of the test is rejected for all four regressions performed, indicating that the fixed effects model is preferable for conducting these regressions estimations. The results of Hausmann test for regression with the dependent variable d2e are presented in the Table 10. The results of the Hausmann tests for the dependent variables st_debt2e, It_debt2e, net_debt2e are presented in the Appendix.

Table 10: Hausmann Test for Regression on d2e

\begin{tabular}{|c|c|c|c|c|}
\hline & (b) & $\begin{array}{l}\text { (B) } \\
\text { Random_eff s }\end{array}$ & $\begin{array}{l}(b-B) \\
\text { Difference }\end{array}$ & $\begin{array}{l}\text { Sqrt(diag(V_b-V_B })) \\
\text { S.E. }\end{array}$ \\
\hline rd_exp & .0049348 & -.0182716 & .0232064 & .0217638 \\
\hline Rev & .0767146 & .2365809 & -.1598663 & .0260494 \\
\hline rd2ns & -.012981 & -.0357218 & .0227408 & .0051066 \\
\hline Etr & -.0006176 & .0115498 & -.0121674 & .0051959 \\
\hline Tang & .0144518 & .0795615 & -.0651097 & .016687 \\
\hline Roa & -.0179262 & -.0631035 & .0451773 & .0048909 \\
\hline $\mathrm{Cr}$ & -.0477167 & -.0872203 & .0395036 & .0044474 \\
\hline \multicolumn{5}{|c|}{$\begin{array}{l}\text { Test: Ho: difference in coefficients not systematic } \\
\text { chi2 }(7)=(b-B)^{\prime}\left[\left(V_{-} b-V \_B\right) \wedge(-1)\right](b-B)=175.91 \\
\text { Prob }>\text { chi2 }=0.0000\end{array}$} \\
\hline
\end{tabular}

Source: Author's own calculations.

Thus, the fixed effects model was chosen as the most reliable [2]. However, in the results section, the results obtained from all three models (cross-sectional linear regression model, random effects model and "within" fixed effects model) are presented and analyzed. More detailed calculations can be found in the Appendix.

\section{Results}

\subsection{Results Anticipated}

The expected influence of ETR is statistically significant and positive for both samples and with regard to all dependent variables. The stimulation of impact of factors on debt-to-equity ratio is based on basic linear regression in the case of the European countries sample and on three different models in the case of the BRIC countries sample. 
For the BRIC countries sample, in the case of null hypotheses fulfillment, the expected direction of independent variables vis-à-vis the dependent variable impact is the same as that for the European countries sample and is arranged as follows in the Table 11 [the expectations are based on the existing literature analyses].

Table 11: Expected Direction of Independent Variables Impact on Capital Structure

\begin{tabular}{|l|l|}
\hline Variable & Direction \\
\hline rd_exp & - \\
\hline Rev & + \\
\hline rd2ns & - \\
\hline ETR & + \\
\hline Tang & - \\
\hline ROA & - \\
\hline
\end{tabular}

Source: Author's own calculations.

For both data samples we expect the ETR coefficient to be significant around the $5 \%$ level, and for the European countries sample we expect the coefficient before different types of programs to be insignificant due to a low participation level of firms in these programs. We expect coefficients pertaining to the size of the company, which is expressed by revenue, to be significant for both data samples as well as those related to ROA and tangibility. The degree of innovativeness indicated by the independent variables $R \& D$ expenditure and $R \& D$ to Net Sales is expected to be significant.

\subsection{Results Obtained from the BRIC Countries Data Sample}

Three econometrics models were applied to estimate ETR impact on debt-to equity ratio. All three models were estimated for four dependent variables, presenting four different debt-to-equity ratios. First, basic linear regression was conducted. The results in the Table 12 were obtained for different debt-to-equity ratios.

Table 12: Condensed Linear Regression Results

\begin{tabular}{|l|l|l|l|l|}
\hline & $\begin{array}{l}\text { Coef. } \\
\text { [d2e reg.] }\end{array}$ & $\begin{array}{l}\text { Coef. } \\
\text { [net_debt2e } \\
\text { reg.] }\end{array}$ & $\begin{array}{l}\text { Coef. } \\
\text { [st_debt2e reg.] }\end{array}$ & $\begin{array}{l}\text { Coef. } \\
\text { [lt_debt2e reg.] }\end{array}$ \\
\hline rd_exp & $-.0555386^{* *}$ & $-.091976^{* * *}$ & $-.0651069^{* * *}$ & $-.111694^{* * *}$ \\
\hline rev & $.2790713^{* * *}$ & $.2318904^{* * *}$ & $.181609^{* * *}$ & $.2656083^{* * *}$ \\
\hline rd2ns & $-.0416375^{* * *}$ & $-.03658^{* *}$ & $-.0272268^{* *}$ & -.0218436 \\
\hline
\end{tabular}




\begin{tabular}{|l|l|l|l|l|}
\hline ETR & $.0287206^{*}$ & -.0202398 & .0021585 & .0261884 \\
\hline tang & $.1033259^{* * *}$ & $.049982^{* *}$ & $.0775271^{* * *}$ & $.1075877^{* * *}$ \\
\hline ROA & $-.1206119^{* * *}$ & $-.0910048^{* * *}$ & $-.1229988^{* * *}$ & $-.10105^{* * *}$ \\
\hline CR & $-.1541001^{* * *}$ & $-.056695^{* * *}$ & $-.1370199^{* * *}$ & $-.111694^{* * *}$ \\
\hline _cons & $-1.454451^{* * *}$ & $-4.437883^{* * *}$ & $-4.149844^{* * *}$ & $.2656083^{* * *}$ \\
\hline $\begin{array}{l}* * * \\
\text { ** Significant on 1\% significance level } \\
\text { * Significant on 5\% significance level }\end{array}$ \\
\hline
\end{tabular}

Source: Author's own calculations.

For the most part, independent variables have significant influence on debt-toequity ratios (on a level of at least $10 \%$ significance); $R \& D$ expenditures, $R \& D$ to net sales, ROA and current ratio mostly negatively influence total debt-to-total equity ratio, while revenue, ETR and tangibility positively influence this ratio. These results partly contradict those anticipated [for tangibility, which were expected to have negative coefficient]. Concerning the effect of ETR on debt-to-equity, the coefficient pertaining to ETR is statistically insignificant in all cases except with regard to total-debt-to-totalequity regression case, where it is statistically significant only at a level of $10 \%$.

Secondly, a random effects model regression was conducted. The results were obtained for different debt-to-equity ratios are shown in the Table 13.

Table 13: Condensed Random Effects Model Regression Results

\begin{tabular}{|l|l|l|l|l|}
\hline & $\begin{array}{l}\text { Coef. } \\
\text { [d2e reg.] }\end{array}$ & $\begin{array}{l}\text { Coef. } \\
\text { [net_debt2e reg.] }\end{array}$ & $\begin{array}{l}\text { Coef. } \\
\text { [st_debt2e reg.] }\end{array}$ & $\begin{array}{l}\text { Coef. } \\
\text { [lt_debt2e reg.] }\end{array}$ \\
\hline rd_exp & -.0182716 & $-.0596394^{* * *}$ & $-.0357439^{*}$ & $-.0622519^{* *}$ \\
\hline rev & $.2365809^{* * *}$ & $.1708834^{* * *}$ & $.1501235^{* * *}$ & $.1893761^{* * *}$ \\
\hline rd2ns & $-.0357218^{* * *}$ & $-.0219142^{*}$ & $-.0250986^{* * *}$ & -.0195287 \\
\hline etr & .0115498 & $-.0221845^{*}$ & -.0032216 & -.0001264 \\
\hline tang & $.0795615^{* * *}$ & $.0419873^{*}$ & $.0597574^{* * *}$ & .0355873 \\
\hline roa & $-.0631035^{* * *}$ & $-.0678415^{* * *}$ & $-.0478053^{* * *}$ & $-.0530971^{* * *}$ \\
\hline cr & $-.0872203^{* * *}$ & $-.0300755^{* * *}$ & $-.0713136^{* * *}$ & -.0080609 \\
\hline cons & $-1.362515^{* * *}$ & $-3.851275^{* * *}$ & $-4.216747^{* * *}$ & $-5.409316^{* * *}$ \\
\hline $\begin{array}{l}* * * \\
* * \\
*\end{array}$ Significant on $1 \%$ significant on $5 \%$ significance level level \\
* Significant on $10 \%$ significance level
\end{tabular}

Source: Author's own calculations. 
Independent variables significantly influence debt-to-equity ratios at a level of at least $10 \%$ significance, except for ETR, which doesn't have a significant impact on debt-to-equity ratios but significantly influences the net_debt-to-equity ratio at only a $10 \%$ level; R\&D expenditures, R\&D to Net Sales, ROA and current ratio mostly negatively influence the total-debt-to-total-equity ratio, while revenue, ETR and tangibility positively influence this ratio. These results partly contradict those anticipated [ETR was expected to have positive influence on dependent variable while tangibility was expected to have a negative influence].

Thirdly, the most reliable results according to the Hausmann test were obtained from fixed effects model regressions. The results were received for different debtto-equity ratios and shown in the Table 14.

Table 14: Condensed Fixed Effects Model Regression Results

\begin{tabular}{|l|l|l|l|l|}
\hline & $\begin{array}{l}\text { Coef. } \\
\text { [d2e reg.] }\end{array}$ & $\begin{array}{l}\text { Coef. } \\
\text { [net_debt2e reg.] }\end{array}$ & $\begin{array}{l}\text { Coef. } \\
\text { [st_debt2e reg.] }\end{array}$ & $\begin{array}{l}\text { Coef. } \\
\text { [lt_debt2e reg.] }\end{array}$ \\
\hline rd_exp & .0049348 & $-.0596413^{* *}$ & -.0248716 & .0393842 \\
\hline rev & $.0767146^{* *}$ & -.0340122 & $.0759691^{* * *}$ & .0010999 \\
\hline rd2ns & -.012981 & .0054019 & -.0142254 & -.0136416 \\
\hline etr & -.0006176 & -.0202769 & -.0051857 & -.0241419 \\
\hline tang & .0144518 & .0191269 & .0270042 & $-.0283033^{*}$ \\
\hline roa & -.0179262 & $-.0475519^{* * *}$ & $-.0162388^{*}$ & .0164138 \\
\hline cr & $-.0477167^{* * *}$ & -.0117541 & $-.0480903^{* * *}$ & $-2.185445^{* *}$ \\
\hline _cons & $1.5479^{*}$ & .6914052 & $-2.868104^{* * *}$ & .0393842 \\
\hline $\begin{array}{l}\text { *** Significant on } 1 \% \text { significance level } \\
\text { ** Significant on 5\% significance level } \\
\text { * Significant on 10\% significance level }\end{array}$ \\
\hline
\end{tabular}

Source: Author's own calculations.

This model presents significant contradictions to the results of previous models; when it comes to direction of influence, it contradicts the cross-sectional regression model in ETR and presents contradictions in the case of total-debt-to-total-equity ratios in $R \& D$ to net sales coefficients. In some cases, only revenue, $R \& D$ expenses, ROA and current ratios significantly influence debt-to-equity ratios to at least a $5 \%$ level of significance. ETR does not have a significant impact on debt-to-equity ratios and has a negative coefficient. These results do not contradict the anticipated results for significant coefficients. 


\section{Conclusion}

This study is devoted to revealing the influence of taxation on the capital structure of innovative companies in BRIC countries. To our knowledge, there is no other research which would investigate all three factors simultaneously, namely influencing capital structure, specificity of capital structure of innovative companies and taxation influence on capital structure in BRIC simultaneously. We supplement this analysis by investigating how different types of tax incentive programs influence capital structure through influence on debt-to-equity ratios, but since this analysis is yet impossible to apply to BRIC countries because of a lack of sufficient data, we have applied it to the set of European countries.

We investigate four hypotheses connected with taxation influence on capital structure in BRIC countries. This investigation can be useful for governments to estimate ETR influence on capital structure choice and how to make a trade-off decision between increasing tax rate and collecting more taxes, or stimulating companies to take on less debt and less risks. Moreover, an additional part of the research (dedicated to the influence of different tax incentive programs on debtto-equity ratios) can help governing parties to make a decision on choice between tax incentive programs and draw conclusions about the extent of their influence on the choice of capital structure. Conscious interaction between business and government through tax policy leads to an increase in efficiency for the whole economy. Therefore, it is important for managers to understand how much debt financing is needed, while government decision makers should understand how to use tax policy to improve the economic environment throughout the country.

The results of the presented data analysis disproved the proposed null hypotheses both for data on BRIC countries and for data from European countries. The results show the absence of significant impact of the tax rate on the capital structure and also indicate the absence of a significant impact of tax incentive programs on capital structure.

The possibility of further development of this research is important, which would entail conducting a deeper analysis and consider the impact of incentivized tax programs on the capital structure of developed countries using panel data, since rejection of null hypotheses in this part of the study in our case may be due to an insufficient number of observations. Moreover, the same can be done with BRIC countries when the required sufficient data is available. Also, an interesting development of the research would be the inclusion in the analysis of new additional variables, such as investment loans and depreciation.

Today, there is still a lack of concise financial literature on developing countries and on the influence of taxation in particular. This study is devoted to partly closing this analytical gap. 


\section{References}

Aghion P. et al. Technology and Financial Structure: Are Innovative Firms Different?, 2(2-3) Journal of the European Economic Association 277 (2004).

Hsu P.-H. et al. Financial Development and Innovation: Cross-Country Evidence, 112(1) Journal of Financial Economics 116 (2014).

Karkinsky T. \& Riedel N. Corporate Taxation and the Choice of Patent Location Within Multinational Firms, 88(1) Journal of International Economics 176 (2012).

Morse S.C. \& Allen E.J. Innovation and Taxation at Start-up Firms, 69(3) Tax Law Review 357 (2016).

\section{Information about the authors}

Elena Makeeva (Moscow, Russia) - Member of Corporate Finance Center, School of Finance, National Research University Higher School of Economics (26 Shabolovka St., Moscow, 119049, Russia; e-mail: len-makeeva@yandex.ru).

Irina Mikhaleva (Moscow, Russia) - Master Degree Student, Member of Corporate Finance Center, School of Finance, National Research University Higher School of Economics (26 Shabolovka St., Moscow, 119049, Russia; e-mail: iamikhaleva@ edu.hse.ru). 